\title{
An Optical Sensor for Dengue Envelope Proteins Using Polyamidoamine Dendrimer Biopolymer-Based Nanocomposite Thin Film: Enhanced Sensitivity, Selectivity, and Recovery Studies
}

\author{
Nur Alia Sheh Omar ${ }^{1,2}$, Yap Wing Fen ${ }^{1,2, *(\mathbb{D})}$, Irmawati Ramli ${ }^{1}\left(\mathbb{D}\right.$, Amir Reza Sadrolhosseini ${ }^{2}$, Jaafar Abdullah ${ }^{1}(\mathbb{D}$, \\ Nor Azah Yusof ${ }^{1,2}$, Yasmin Mustapha Kamil ${ }^{3}$ (D) and Mohd Adzir Mahdi ${ }^{4}$ \\ 1 Faculty of Science, Universiti Putra Malaysia, UPM Serdang 43400, Selangor, Malaysia; \\ nuralia.upm@gmail.com (N.A.S.O.); irmawati@upm.edu.my (I.R.); jafar@upm.edu.my (J.A.); \\ azahy@upm.edu.my (N.A.Y.) \\ 2 Institute of Advanced Technology, Universiti Putra Malaysia, UPM Serdang 43400, Selangor, Malaysia; \\ amir1348@gmail.com \\ 3 inLAZER Dynamics Sdn Bhd, InnoHub Unit, Putra Science Park, Universiti Putra Malaysia, \\ UPM Serdang 43400, Selangor, Malaysia; yasminmustaphakamil@gmail.com \\ 4 Wireless and Photonics Network Research Centre, Faculty of Engineering, Universiti Putra Malaysia, \\ UPM Serdang 43400, Selangor, Malaysia; mam@upm.edu.my \\ check for \\ updates \\ * Correspondence: yapwingfen@gmail.com
}

Citation: Omar, N.A.S.; Fen, Y.W.; Ramli, I.; Sadrolhosseini, A.R.; Abdullah, J.; Yusof, N.A.; Kamil, Y.M.; Mahdi, M.A. An Optical Sensor for Dengue Envelope Proteins Using Polyamidoamine Dendrimer Biopolymer-Based Nanocomposite Thin Film: Enhanced Sensitivity, Selectivity, and Recovery Studies. Polymers 2021, 13, 762. https:// doi.org/10.3390/polym13050762

Academic Editor: Ângela Maria Almeida de Sousa

Received: 2 February 2021

Accepted: 20 February 2021

Published: 28 February 2021

Publisher's Note: MDPI stays neutral with regard to jurisdictional claims in published maps and institutional affiliations.

Copyright: () 2021 by the authors. Licensee MDPI, Basel, Switzerland. This article is an open access article distributed under the terms and conditions of the Creative Commons Attribution (CC BY) license (https:// creativecommons.org/licenses/by/ $4.0 /)$.
Abstract: This paper proposes a novel idea to enhance the sensitivity and selectivity of surface plasmon resonance (SPR) optical sensor for detection of dengue virus type-2 envelope proteins (DENV-2 E-proteins) using polyamidoamine (PAMAM) dendrimer biopolymer-based nanocomposite thin film. For this purpose, two ranges of DENV-2 E-protein concentrations, i.e., 0.000008-0.0001 nM and $0.00008-0.005 \mathrm{nM}$ were evaluated, and the lowest detectable concentration was achieved at $0.00008 \mathrm{nM}$. The incorporation of PAMAM dendrimer-based nanocomposite thin film with an SPR sensor exhibited a significant increase in sensitivity and binding affinity to a lower range DENV-2 E-protein concentrations. Moreover, the proposed sensor displayed good selectivity towards DENV-2 E-proteins and have an average recovery of $80-120 \%$. The findings of this study demonstrated that PAMAM dendrimer-based nanocomposite thin film combined with SPR sensor is a promising diagnostic tool for sensitive and selective detection of DENV-2 E-proteins.

Keywords: polyamidoamine dendrimer; reduced graphene oxide; dengue virus

\section{Introduction}

Surface plasmon resonance (SPR) has become an important optical sensing technique in the field of biomedical analysis, food safety, and chemistry because of their high sensitivity, fast analysis speed, real time, and label free detection [1-5]. In general, SPR is a direct-reading detection method that monitors the changes in refractive index on the gold surface when the surface plasmon is excited by the evanescent field under total internal reflection condition. Such resonance takes place at a certain incident angle with the formation of a minimum dip of reflected light intensity. This dip location is a robust function of the medium's refractive index close to the interface, hence its potential use as a sensitive refractive index sensor [6-12]. However, the sensitivity of gold film-based SPR sensor is limited to the detection of any solutions that have a similar refractive index as the mass change on the binding is not sufficient to cause a detectable change in refractive index [13-16]. To overcome this limitation, a gold film surface was functionalized with a high density of biomolecules [17-25].

Engineering the SPR-gold film with high surface area materials are beneficial for enhancing the sensitivity of SPR sensors. Polyamidoamine (PAMAM) dendrimers are one 
of the smallest and most precise biopolymers available today since they were commercially available and, more importantly, could easily act as bio-conjugating reagents to increase the active sites of the sensor [26-28]. They are hydrophilic and are a family of highly branched macromolecules with different active functional groups outside its surface and so have advantages over other micromolecules due to monodispersity, modifiable surface functionalities, and high mechanical and chemical stability [29-32]. There is a demand for enhancing the adsorption of biomolecules (such as dengue proteins), and amine-reduced graphene oxide $\left(\mathrm{NH}_{2} \mathrm{rGO}\right)$ nanocomposites are beneficial to bind directly to a globularshaped polyamidoamine (PAMAM) dendrimer without affecting their biological activity. In particular, many authors have demonstrated the capability of rGO as a sensing film because of its unique physiochemical properties including good reaction yields, excellent stability, reliable preparation, large surface areas, and good biocompatibility [33-42]. This $\mathrm{NH}_{2} \mathrm{rGO}-\mathrm{PAMAM}$ composite is believed to have a great sensing performance in detecting and quantifying the dengue virus.

Dengue virus (DENV) is a mosquito-borne viral disease, comprising of four serotypes of the virus, i.e., DENV-1, DENV-2, DENV-3, and DENV-4 [43-45]. Infections with DENV often appear as non-specific symptoms such as mild fever, headache, and body rashes, and further delayed diagnosis might lead to dengue hemorrhagic fever, dengue shock syndrome, or death [46-50]. In this case, optical diagnostic has been vastly utilized in the relevance to dengue disease compared to the laboratory serological and commercial kits [51-53]. This is because the optical diagnostic, mainly for SPR sensor, focus on the measurement of a change in the optical properties of the sensor surface due to the adsorption of analyte. Most works on DENV detection using SPR sensor were listed in Table 1 [54-63].

Table 1. Dengue virus (DENV) detection using surface plasmon resonance (SPR) sensor.

\begin{tabular}{ccc}
\hline Targeted Determinant & Detection Limit & References \\
\hline IgM & - & {$[54-57]$} \\
DENV & - & {$[58]$} \\
DENV-2 NS1 & $0.25 \mathrm{ng} / \mathrm{mL}$ & {$[59]$} \\
NS1 proteins & $1 \mathrm{nM}$ & {$[60]$} \\
NS1 & $5.73 \mathrm{pg} / \mathrm{mm}^{2}$ & {$[61]$} \\
IgM & $2.125 \mathrm{pM}$ & {$[62]$} \\
NS1 proteins & $0.3 \mathrm{nM}$ & {$[63]$} \\
\hline
\end{tabular}

It can be observed that the most targeted determinants were specific DENV antibodies and NS1 virus/proteins. Despite the success of DENV detection by using SPR, both determinants have some limitations in providing the early detection of DENV. The antibodies are released in response to DENV up to 7 days post-infection, while NS1 products are produced within 5 days of infection after cleavage from E-proteins. Additionally, detection of antibodies (IgM and IgG) is not always highly specific to DENV as it can be cross-reactive against other flavivirus, while detection of NS1 tends to be less sensitive in secondary dengue (DENV-2) infection than in primary dengue (DENV-1) infection [64-67]. To overcome these issues, the envelope (E) proteins of the DENV-2 has become our determinant. The E-proteins are the protein structures that form the coat of the host-virus itself, therefore it is enough to mount sufficient immune response earlier (in the viremia phase).

In this work, we propose to develop polyamidoamine dendrimer biopolymer-based nanocomposite thin film to improve the performance of SPR sensor for detection of dengue envelope proteins in terms of their sensitivity, binding affinity, and selectivity. Despite this interest, no other study to the best of our knowledge has achieved lowest detectable concentration DENV-2 E-proteins at $0.00008 \mathrm{nM}(0.08 \mathrm{pM})$. The stability and spike recovery of the proposed SPR sensor was also evaluated in this work. 


\section{Materials and Methods}

\subsection{Reagents}

Dithiobis(succinimidyl undecanoate) (DSU, $>90 \%$ Dojindo, Japan), graphene oxide (Graphanea, Gipuzkoa, Spain), Polyamidoamine dendrimer (PAMAM, ethylenediamine, generation 4.0, 10 weight percent (wt. \%) in methanol, Sigma Aldrich, St. Louis, MO, USA), Ethylenediamine (EDA, >99\%, Sigma Aldrich, St. Louis, MO, USA), N-hydroxysuccinimide (NHS, 98\%, Sigma Aldrich, St. Louis, MO, USA), 1-Ethyl-3-(3-(dimethylaminopropyl) carbodiimide hydrochloride (EDC, Thermo Fisher Scientific, Waltham, MA, USA), recombinant dengue virus type 2 envelope protein (DENV-2 E-proteins, Meridian Life Science, Inc., Tennessee, United States), specific monoclonal antibodies dengue virus type 2 envelope protein (IgM, Meridian Life Science, Inc., Memphis, TN, USA), recombinant dengue virus type 1 envelope protein (DENV-1 E-proteins, Meridian Life Science, Inc., Memphis, TN, USA), and recombinant zika envelope proteins (ZIKV, Mybiosource, San Diego, CA, USA) were used without further purification.

\subsection{Preparation of $\mathrm{NH}_{2}$ rGO-PAMAM-Based Nanocomposite Thin Film}

Preparation of $\mathrm{NH}_{2} \mathrm{rGO}$ was begun by amalgamating the graphene oxide with EDC for $5 \mathrm{~min}$ and was later added by EDA. The mixture was then stirred vigorously with the aid of the magnetic stirrer to dissolve the suspension until it turns to dark black. The suspension was washed with ethanol and centrifuged immediately at high speed to discard the excess EDA and EDC. Then, the obtained $\mathrm{NH}_{2} \mathrm{rGO}$ was dried at $60{ }^{\circ} \mathrm{C}$ for at least $1 \mathrm{~h}$. After the drying process, the resulting product was mixed with PAMAM solution. Unless otherwise stated, all the antibodies and antigen solutions were diluted in $10 \mathrm{mM}$ phosphate buffered saline (PBS) at $\mathrm{pH}$ 7.4. All chemicals used in this work were of reagents or higher grade.

A cleaned glass film (Menzel glass, $2.4 \mathrm{~cm} \times 2.4 \mathrm{~cm}$ ) was sputtered with a thin gold layer of $48 \mathrm{~nm}$ thick as a sensitive element of the SPR sensor using SC7640 Sputter Coater $(\mathrm{I}=20 \mathrm{~mA})$. To generate self-assembled monolayer (SAM), a gold-coated film was rinsed with water and ethanol followed by drying under nitrogen flow. The dimethyl sulfoxide solution containing $2 \mathrm{mM}$ dithiobis (succinimidyl undecanoate) was prepared for adsorptions of thiol and disulphide onto substrate film. After $24 \mathrm{~h}$, the SAM was formed and then thoroughly rinsed with acetone and subsequently with phosphate-buffered saline (PBS, pH 7.4). Briefly, an exact amount of $0.5 \mathrm{~mL}$ of the $\mathrm{NH}_{2}$ rGO-PAMAM composite solution was dropped onto the substrate surface followed by spinning for $30 \mathrm{~s}$. Thereafter, a substrate was incubated in EDC/NHS solution for $30 \mathrm{~min}$ and was later subjected to spinning process. After cross-linking, the substrate was immobilized with specific DENV antibodies (0.01 $\mu \mathrm{M}$ in PBS) to detect DENV-2 E-proteins selectively. The design of $\mathrm{Au} / \mathrm{DSU} / \mathrm{NH}_{2} \mathrm{rGO}-\mathrm{PAMAM} / \mathrm{IgM}$ sensor film is shown in Figure 1.

\subsection{Incorporation of $\mathrm{Au} / \mathrm{DSU} / \mathrm{NH}_{2} r G O-P A M A M / I g M$ Sensor Film into SPR System}

The SPR measurement was then performed using a custom-built SPR system under Kretschmann configuration, which consisted of a helium-neon laser, an optical stage features an angular resolution of $0.001^{\circ}$ with a stepper motor driven version (Newport MM 3000), a polarizer, an optical chopper (SR 540), and a prism. In this system, PBS solution was used to execute the baseline data. Approximately, $100 \mu \mathrm{L}$ of diluted DENV-2 E-proteins was subsequently injected into the o-ring. All experiments were repeated three times with a new sensor film for each concentration of DENV-2 E-proteins. The increment/decrement of SPR reflectance was calculated by taking the difference between the SPR reflectance curves of the PBS solution and the respective analyte solution, DENV-2 E-proteins. 
(a)

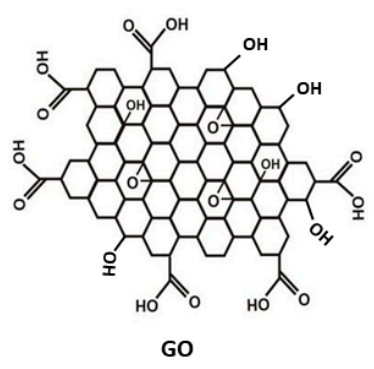

(64)

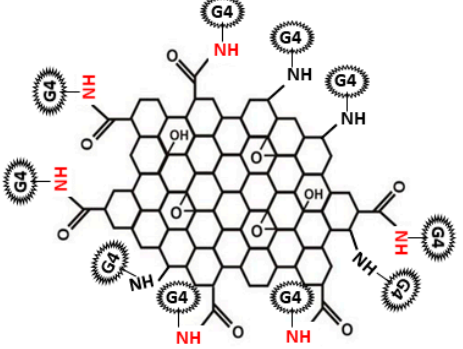

$\mathrm{NH}_{2}$ rGO-PAMAM

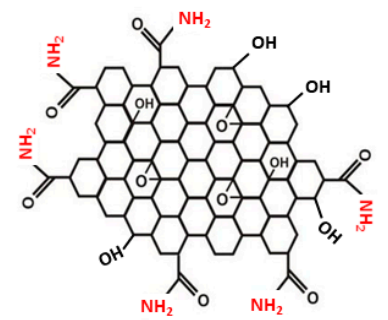

$\mathrm{NH}_{2} \mathrm{rGO}$

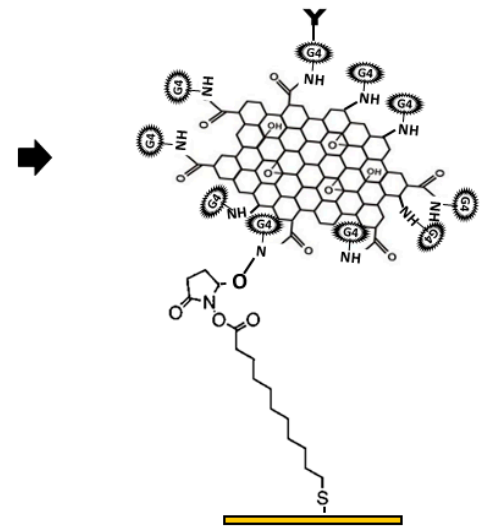

$\mathrm{Au} / \mathrm{DSU} / \mathrm{NH}_{2}$ rGO-PAMAM/IgM

(b)

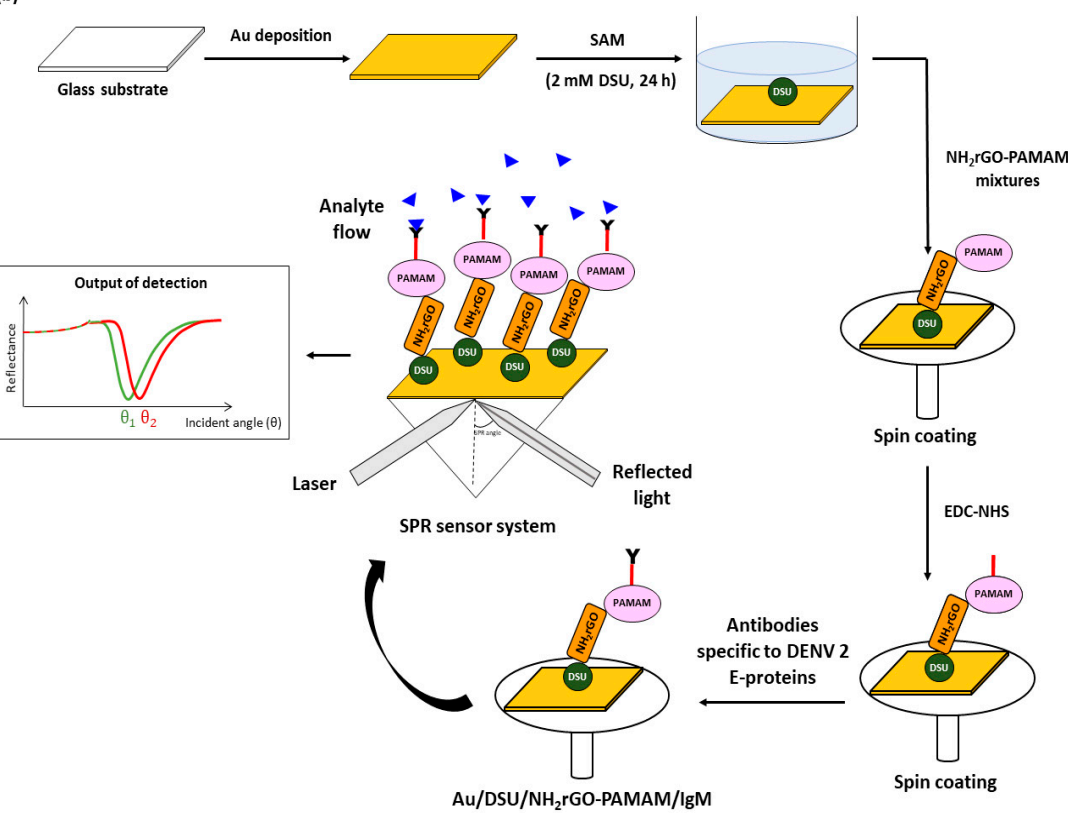

Figure 1. Illustration of (a) possible mechanism for the preparation of DSU/ $\mathrm{NH}_{2} \mathrm{rGO}-\mathrm{PAMAM} / \mathrm{IgM}$ and $(\mathbf{b})$ sensor film preparation.

\section{Results}

3.1. FTIR Analysis of Au/DSU/NH ${ }_{2} r G O-P A M A M / I g M$ Sensor Film

FTIR spectra of DSU, $\mathrm{NH}_{2} \mathrm{rGO}$, PAMAM, and IgM was conducted using FTIR spectroscopy (VERTEX 70) to confirm the development of $\mathrm{Au} / \mathrm{DSU} / \mathrm{NH}_{2} \mathrm{rGO}-\mathrm{PAMAM} / \mathrm{IgM}$ sensor film (Figure 2). Four characteristic peaks of DSU positioned at $3420 \mathrm{~cm}^{-1}, 1656 \mathrm{~cm}^{-1}$, $1424-1300 \mathrm{~cm}^{-1}, 1017-940 \mathrm{~cm}^{-1}$, and $650-690 \mathrm{~cm}^{-1}$ can be attributed to the O-H stretching, 
$\mathrm{C}=\mathrm{C}$ stretching, $\mathrm{C}-\mathrm{H}$ bending, $\mathrm{C}-\mathrm{H}$ bending, and Au-S band, respectively. In the spectrum of $\mathrm{NH}_{2} \mathrm{rGO}$, there are bands from N-H stretching $\left(3200-3346 \mathrm{~cm}^{-1}\right)$, Amide I $\left(1600 \mathrm{~cm}^{-1}\right)$, C-N stretching (1250-1344 $\left.\mathrm{cm}^{-1}\right)$, and C-O stretching $\left(1051 \mathrm{~cm}^{-1}\right)$ [68]. For PAMAM spectrum, the obvious three peaks were attributed to the N-H stretching, Amide I, and C-O stretching $[69,70]$, while two absorption peaks in IgM spectrum was assigned to the $\mathrm{N}-\mathrm{H}$ stretching and Amide I [71,72]. As seen from the spectrum of $\mathrm{Au} / \mathrm{DSU} / \mathrm{NH}_{2} \mathrm{rGO}-$ PAMAM/IgM sensor film, there are the absorption bands due to the $\mathrm{N}-\mathrm{H}$ stretching, Amide I, Amide II, C-O stretching, and Au-S band. The successful of IgM immobilization can be confirmed by a reduction of $\mathrm{N}-\mathrm{H}$ band and the appearance of a small peak of Amide II. Upon introduction of DENV into the sensor film, the peaks for $\mathrm{N}-\mathrm{H}$ stretching and Amides faced an intensity reduction, proving the immunological reaction between the antibodies and DENV-2 E-proteins [73].

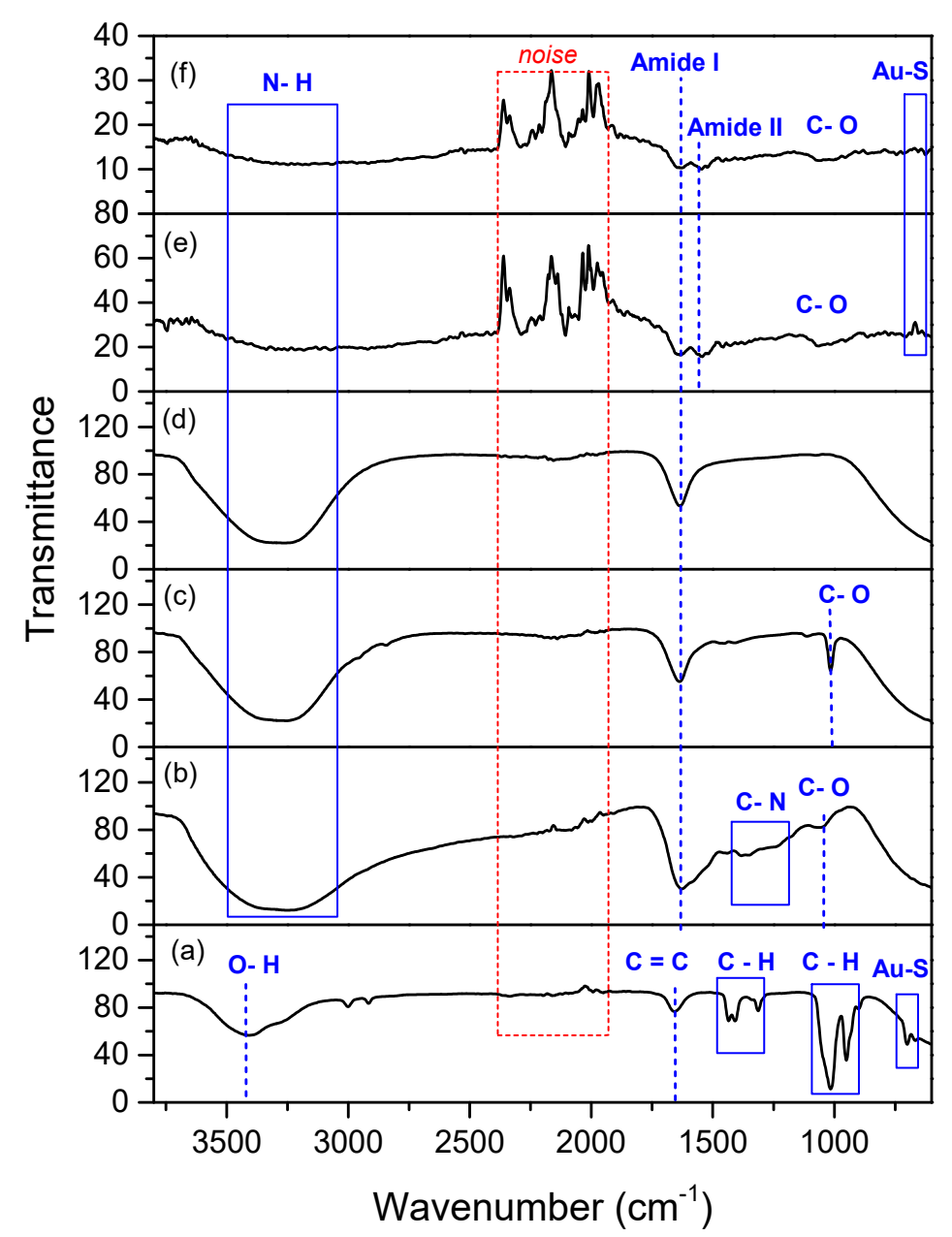

Figure 2. FTIR spectra of (a) DSU; (b) $\mathrm{NH}_{2} \mathrm{rGO}$; (c) PAMAM; (d) IgM; (e) Au/DSU/NH $\mathrm{N}_{2} \mathrm{rGO}$ PAMAM/IgM sensor film; (f) Au/DSU/ $\mathrm{NH}_{2}$ rGO-PAMAM/IgM sensor film exposed to DENV-2 E-proteins.

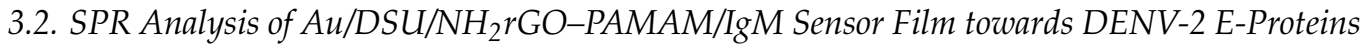
3.2.1. SPR Reflectivity

Figure 3 shows the SPR reflectance curves for $\mathrm{Au} / \mathrm{DSU} / \mathrm{NH}_{2} \mathrm{rGO}-\mathrm{PAMAM}$ thin film with high-range DENV-2 E-protein concentrations of 0.00008-0.005 nM. Prior to the analyte detection, the PBS solution was injected into the o-ring, producing a resonance angle of $54.213^{\circ}$. The analyte detection was then carried out by injecting the high-range DENV-2 E-protein concentrations of $0.00008-0.005 \mathrm{nM}$ one after another into the o-ring. The first obtained resonance angle of $0.00008 \mathrm{nM}$ of DENV-2 E-proteins was $54.305^{\circ}$. Next, the 
$\mathrm{Au} / \mathrm{NH}_{2} \mathrm{rGO}-\mathrm{PAMAM}$ thin film showed an increase in resonance angles of the incident light towards $54.313^{\circ}, 54.392^{\circ}, 54.400^{\circ}$, and $54.408^{\circ}$ due to the introduction of DENV-2 E-protein concentrations of $0.0001 \mathrm{nM}, 0.0003 \mathrm{nM}, 0.0005 \mathrm{nM}$, and $0.001 \mathrm{nM}$, respectively. The increment of resonance angles can be interpreted as the increment of antigens attached to the sensor surfaces. It was found that the rise in resonance angle shifts of all DENV-2 E-protein concentrations, i.e., $\Delta \theta_{\mathrm{SPR}}=0.092^{\circ}, 0.100^{\circ}, 0.179^{\circ}, 0.187^{\circ}$, and $0.195^{\circ}$, can be associated with the changes in the real part of the refractive index of the sensor surface caused by the binding of DENV-2 E-proteins, which consequently affect the thickness of the sensing layer $[74,75]$. When the introduction of DENV-2 E-proteins was higher than $0.001 \mathrm{nM}$, the reflectance curves remain unchanged at $54.408^{\circ}$ due to the maximum binding of DENV-2 E-proteins. The observion of this phenomenon is mainly due to the difficulty of SPR evanescent wave in penetrating the thick dielectric layer, which then reduces the sensitivity of the SPR sensor $[76,77]$.

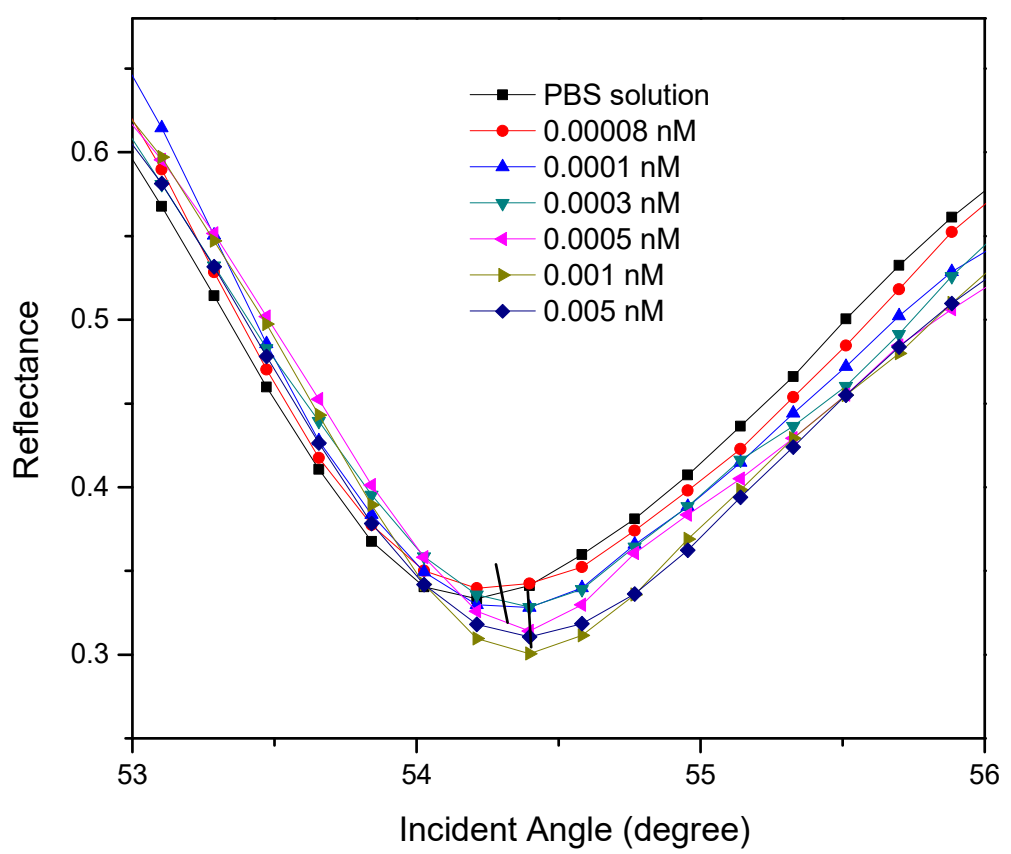

Figure 3. The reflectance curves of $0.00008-0.005 \mathrm{nM}$ of DENV-2 E-protein detection.

Next, the $\mathrm{Au} / \mathrm{DSU} / \mathrm{NH}_{2} \mathrm{rGO}-\mathrm{PAMAM} / \mathrm{IgM}$-based SPR sensor response towards a lower range of DENV-2 E-protein concentration $(0.000008 \mathrm{nM}$ to $0.0001 \mathrm{nM})$ was conducted to determine the lowest detectable concentration for DENV-2 E-proteins, or on the other hand, to determine the detection limit obtained by this sensor. In this regard, the limit of detection (LOD) is derived by the capability of the sensor to distinguish the SPR response of DENV-2 E-protein detection and reference solution detection [78]. The results depicted in Figure 4 show that the resonance angles for $0.000008-0.00006 \mathrm{nM}$ of DENV-2 E-proteins remain unchanged from the resonance angle of PBS solution, $54.211^{\circ}$. This is owing to the weak interaction of the low refractive index of DENV-2 E-proteins solution and the sensor layer, which cannot significantly increase the refractive index of the sensing layer. However, with increasing of DENV-2 E-protein concentrations, i.e., $0.00008 \mathrm{nM}$ and $0.0001 \mathrm{nM}$, the resonance angles shifted to the higher angles of $54.311^{\circ}$ and $54.393^{\circ}$, respectively. The increase in the resonance angle is strongly evidenced by the successful detection of DENV-2 E-proteins on the sensor surface, resulting in an increase in the refractive index near a gold layer $[79,80]$. It can be hypothesized that the lower limit of detection of this study is $0.00008 \mathrm{nM}$ as any concentration less than $0.00008 \mathrm{nM}$ is not detectable. The detection limit obtained was then compared with some of the recently published data as shown in Table 2, which clearly shows that the $\mathrm{Au} / \mathrm{DSU} / \mathrm{NH}_{2} \mathrm{rGO}-\mathrm{PAMAM} / \mathrm{IgM}$ sensor film-based SPR sensor has the lowest detection limit so far $[62,63,73,81,82]$. Herein, the inclusion of DSU 
as a self-assembly monolayer and $\mathrm{NH}_{2} \mathrm{rGO}-\mathrm{PAMAM}$ composite as a sensing layer has provided strong support for IgM immobilization for selective detection of dengue virus.

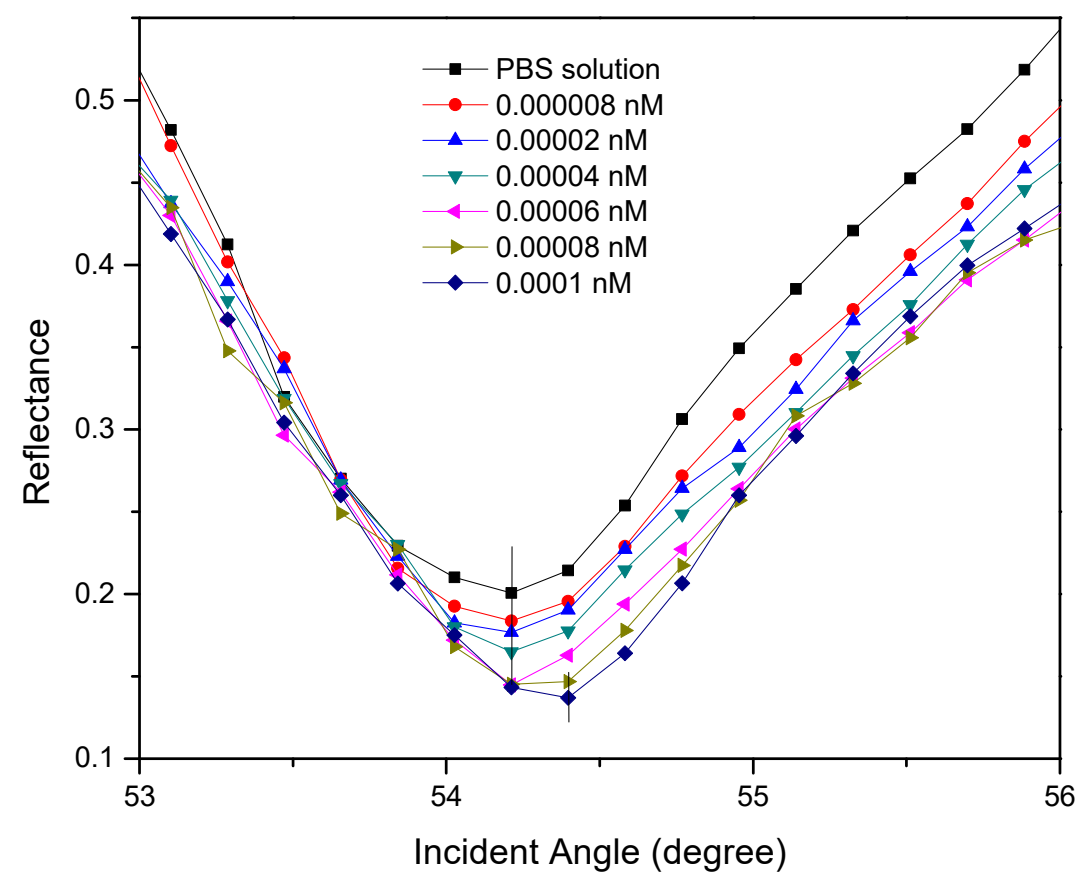

Figure 4. The reflectance curves of 0.000008-0.0001 nM of DENV-2 E-protein detection.

Table 2. Recent studies and comparison of detection limit for DENV based on optical sensor.

\begin{tabular}{|c|c|c|c|c|}
\hline Optical Sensor & Active Layer & Determinant & Detection Limit & References \\
\hline Optical fiber & PAMAM $^{1}$ & DNEV-2 E-proteins & $1 \mathrm{pM}$ & [73] \\
\hline Optical fiber & & DENV NS1 IgG antibody & 200 pM & [81] \\
\hline SPR & CM5/EDC-NHS ${ }^{2}$ & IgM antibody & $2.125 \mathrm{pM}$ & [62] \\
\hline SPR & CMD/EDC-NHS ${ }^{3}$ & NS1 proteins & $0.3 \mathrm{nM}$ & [63] \\
\hline Colorimetric & G4-hemin DNAzyme & $\begin{array}{l}\text { DENV-1 DNA; DENV-2 DNA; } \\
\text { DENV-3 DNA, DENV-4 DNA }\end{array}$ & $\begin{array}{l}8.8 \mathrm{nM} ; 4.9 \mathrm{nM} ; 9.3 \mathrm{nM} ; \\
5.1 \mathrm{nM}\end{array}$ & [82] \\
\hline SPR & $\mathrm{Au} / \mathrm{DSU} / \mathrm{NH}_{2} \mathrm{rGO}-\mathrm{PAMAM}$ & DENV-2 E-proteins & $0.08 \mathrm{pM}$ & This work \\
\hline
\end{tabular}

${ }^{1}$ Polyamidoamine dendrimer, ${ }^{2}$ carboxymethyl dextran matrix/N-ethyl-N-(dimethylaminopropyl) carbodiimide-N-hydroxysuccinimide,

${ }^{3}$ carboxyl methildextrand/N-ethyl-N-(dimethylaminopropyl) carbodiimide-N-hydroxysuccinimide.

\subsubsection{SPR Performances}

Figure 5 shows a linear regression graph of the shift in SPR angle versus DENV-2 Eprotein concentrations ranging from 0.00008 to $0.0005 \mathrm{nM}$. The gradient of the linear fit was $333.896^{\circ} / \mathrm{nM}$ with the $\mathrm{R}^{2}$, of 0.787 (standard deviation \pm 0.02 ). Based on the gradient value, it was concluded that the sensitivity of $\mathrm{Au} / \mathrm{DSU} / \mathrm{NH}_{2} \mathrm{rGO}-\mathrm{PAMAM} / \mathrm{IgM}$ sensor film when detecting DENV-2 E-proteins was $333.896^{\circ} / \mathrm{nM}$. The results clearly indicated that the proposed sensor can be potentially used to detect the lowest concentration of DENV-2 E-proteins with a high sensitivity. This behavior can be understood because of the stronger penetration depth of the SPR evanescent field along the $\mathrm{Au} / \mathrm{DSU} / \mathrm{NH}_{2} \mathrm{rGO}-\mathrm{PAMAM} / \mathrm{IgM}$ sensor film, thus, it can significantly detect the DENV-2 E-proteins as low as $0.00008 \mathrm{nM}$ using SPR technique [83-85]. The association constant, $\mathrm{K}_{\mathrm{A}}$ and dissociation constant, $\mathrm{K}_{\mathrm{D}}$ for the assessment of the interaction affinity were then calculated and found to be $9.345 \mathrm{TM}^{-1}$ and $0.107 \mathrm{pM}$, respectively, with the $\mathrm{R}^{2}$ of 0.977 . The smaller $\mathrm{K}_{\mathrm{D}}$ value revealed that the $\mathrm{Au} / \mathrm{DSU} / \mathrm{NH}_{2} \mathrm{rGO}-\mathrm{PAMAM} / \mathrm{IgM}$ sensor film has a high affinity interaction with the DENV-2 E-proteins and is found to be consistent with the standard $\mathrm{K}_{\mathrm{D}}$ value for protein interaction $\left(\mathrm{K}_{\mathrm{D}}<10 \mathrm{nM}\right)[86,87]$. 


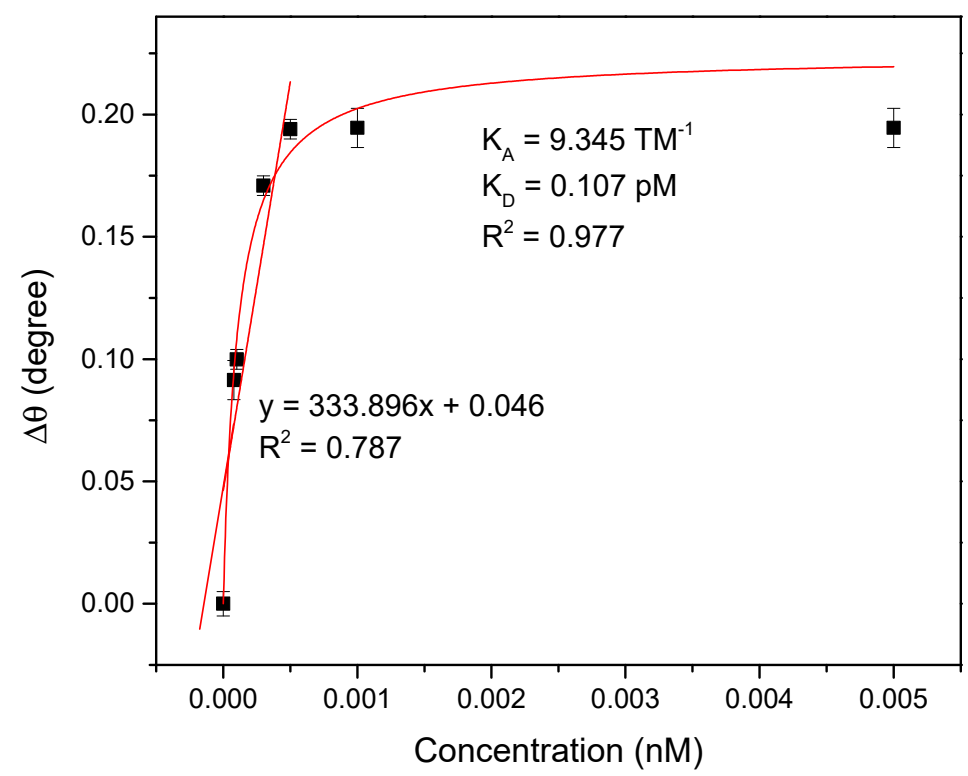

Figure 5. A linear regression graph and Langmuir graph for $\mathrm{Au} / \mathrm{DSU} / \mathrm{NH}_{2} \mathrm{rGO}-\mathrm{PAMAM} / \mathrm{IgM}$ sensor film.

The proposed sensor films were then stored in a refrigerator for three weeks to examine the stability of the sensor for 0.08 pM of DENV-2 E-protein detection. Figure 6 shows that the resonance angle decreased dramatically on the 21st day storage. However, the $\mathrm{Au} / \mathrm{DSU} / \mathrm{NH}_{2} \mathrm{rGO}-\mathrm{PAMAM} / \mathrm{IgM}$ sensor film still provided a good resonance angle shift throughout 7-day storage. This result suggested that the antibodies immobilization on the sensor surface is strongly retained without losing their bonding.

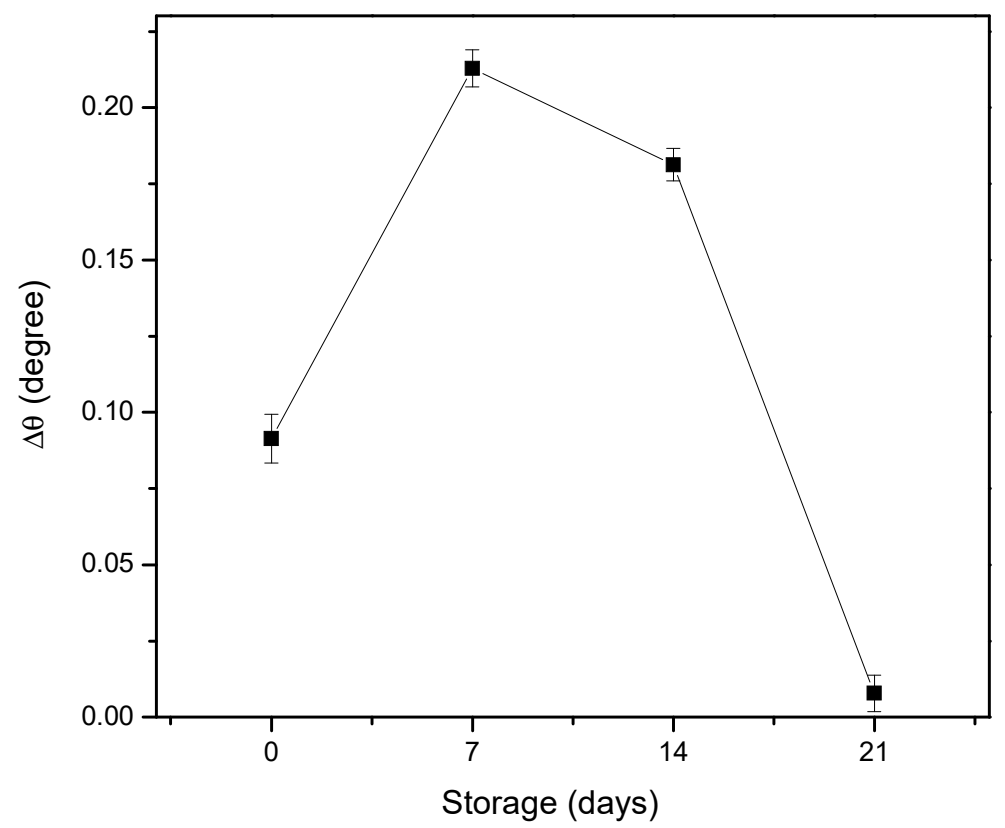

Figure 6. The stability test of $\mathrm{Au} / \mathrm{DSU} / \mathrm{NH}_{2} \mathrm{rGO}-\mathrm{PAMAM} / \mathrm{IgM}$ sensor film.

To evaluate the selectivity performance of the proposed sensor, other $10 \mathrm{pM}$ competitor analytes, i.e., DENV-1 E-proteins, ZIKV E-proteins, HSA, and BSA, were selected and tested against $0.1 \mathrm{pM}$ DENV-2 E-proteins as shown in Figure 7a. As can be observed, the introduction of HSA proteins and DENV-1 E-proteins resulted in a rise in SPR responses, which might be due to the non-specific interactions between proteins and sensor surface. 
As expected, the binding between DENV-1 E-proteins and sensor surface occurred because of $65 \%$ of single-stranded RNA genomes were shared by each serotype of DENV $[88,89]$. Meanwhile, a high SPR response for HSA proteins can be accounted for the excessive proteins in the blood with a molecular weight of $66.4 \mathrm{kDa}$ when compared to $50 \mathrm{kDa}$ DENV1 E-proteins [90,91]. Due to a direct binding between DENV-2 E-proteins and its specific antibodies immobilized on the sensor surface, the SPR response of $0.1 \mathrm{pM}$ of DENV-2 E-protein solution was obviously increased. It is verified that the antibodies immobilized on a sensor surface have a highly selective in detecting DENV-2 E-proteins.

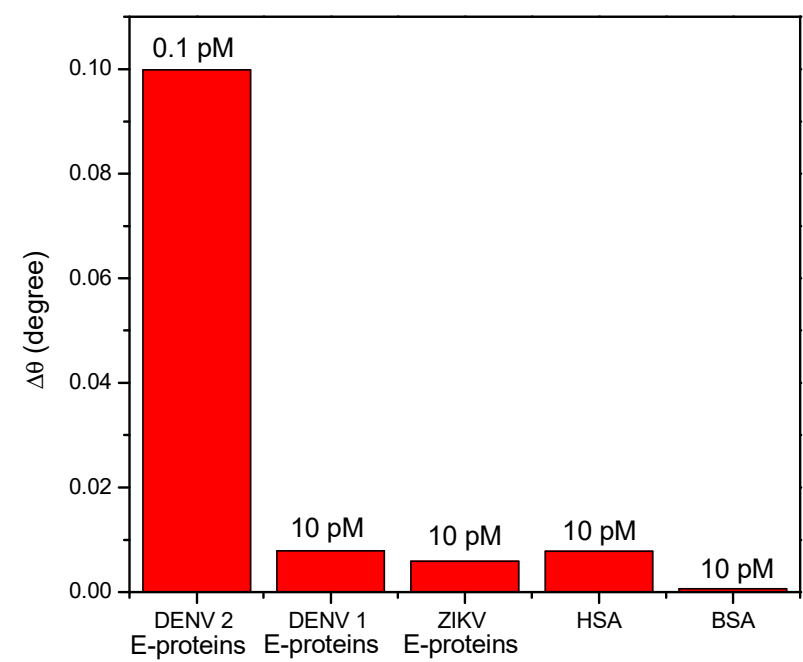

(a)

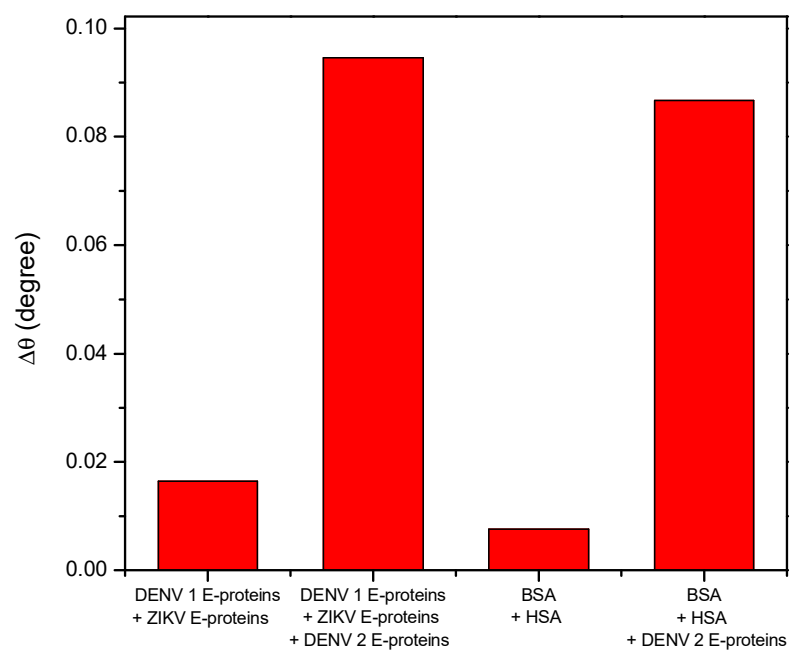

(b)

Figure 7. Selectivity test between $\mathrm{Au} / \mathrm{DSU} / \mathrm{NH}_{2} \mathrm{rGO}-\mathrm{PAMAM} / \mathrm{IgM}$ sensor film and (a) each different analyte; (b) mixture of analytes.

Figure $7 \mathrm{~b}$ depicts the selective shift of SPR angle of DENV-2 E-proteins in multiple analytes solution. The concentrations of each analyte were fixed at $10 \mathrm{pM}$. As expected, a markedly large shift of SPR angle was generated for multiple solutions containing DENV-2 E-proteins compared to other solution that does not have DENV-2 E-proteins. The results suggest that the proposed sensor exhibits excellent selectivity of the proposed sensor towards the sensing of DENV-2 E-proteins. This is due to the stronger binding of a very specific immobilized IgM at $\mathrm{NH}_{2} \mathrm{rGO}-\mathrm{PAMAM}$ sensor layer.

To further validate the applicability of the proposed sensor as DENV immunosensor in real samples, $10 \%$ BSA solutions were spiked into all concentrations of DENV-2 E-proteins under the same procedures. According to the SPR response in Figure 8, the recoveries of DENV-2 E-proteins was calculated and tabulated in Table 3. The obtained average recovery was consistent with acceptable recovery, which is in the range of $80-120 \%$, indicates that the proposed sensor can be used for detection and quantification of DENV-2 E-proteins in real samples [92-95].

Table 3. Spike and recovery results of DENV-2 E-proteins in BSA.

\begin{tabular}{ccccc}
\hline Sample Concentration (pM) & Spike (\%) & $\begin{array}{c}\text { PBS + DENV-2 E-Protein } \\
\text { Resonance Angle (Degree) }\end{array}$ & $\begin{array}{c}\text { BSA + DENV-2 E-Protein } \\
\text { Resonance Angle (Degree) }\end{array}$ & $\begin{array}{c}\text { Recovery (\%) } \\
\text { (1) }\end{array}$ \\
\hline 0.08 & 4.5 & 54.305 & 54.400 & 100.174 \\
0.1 & 4.5 & 54.313 & 54.480 & 100.307 \\
0.5 & 4.5 & 54.392 & 54.496 & 100.191 \\
1 & 4.5 & 54.400 & 54.496 & 100.176 \\
\hline
\end{tabular}




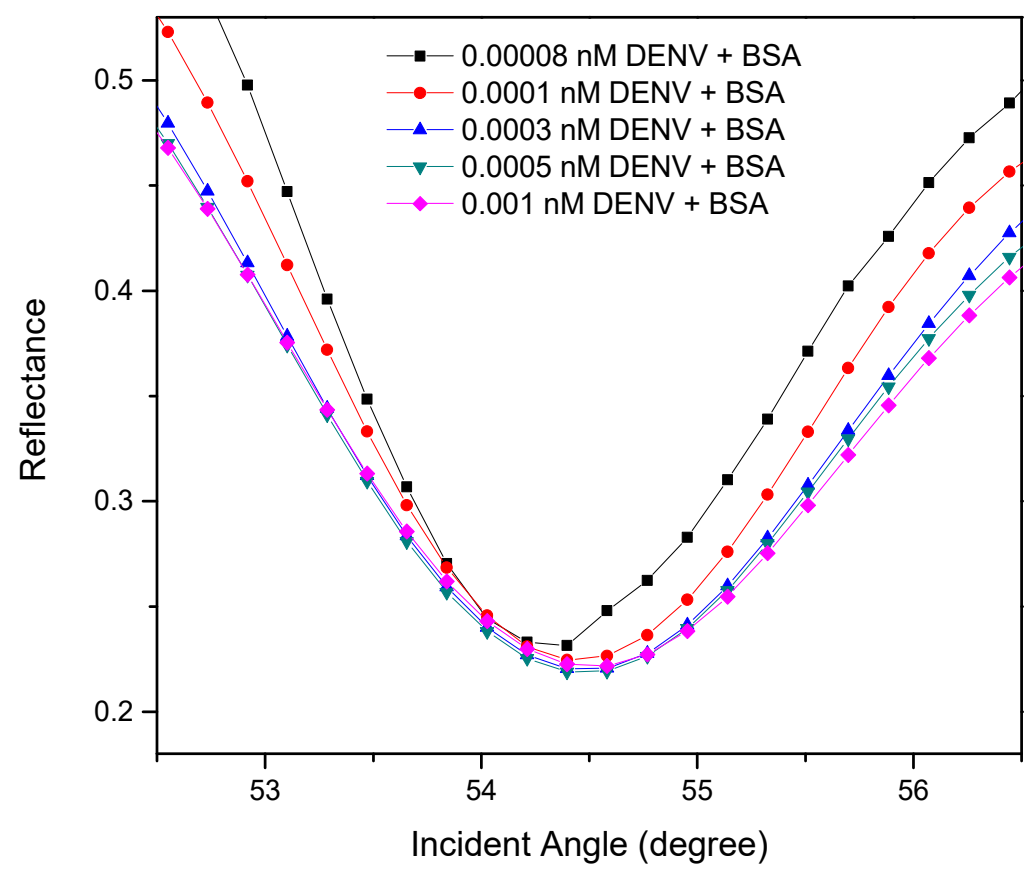

Figure 8. Experimental SPR curves for different concentration of DENV-2 E-proteins in spiked samples.

\section{Conclusions}

In this study, a highly sensitive and selective $\mathrm{Au} / \mathrm{DSU} / \mathrm{NH}_{2} \mathrm{rGO}-\mathrm{PAMAM} / \mathrm{IgM}$ thinfilm-based SPR sensor was successfully developed for detection of DENV-2 E-proteins of $0.000008-0.005 \mathrm{nM}$. The SPR results show that the proposed sensor successfully quantifies the concentration of targeted DENV-2 E-proteins as low as $0.00008 \mathrm{nM}$ with a sensitivity value of $333.896^{\circ} / \mathrm{nM}$. The proposed sensor film also showed a strong binding affinity constant of $9.345 \mathrm{TM}^{-1}$, good stability within 7-day storage, and a good selective response towards DENV-2 E-proteins. Furthermore, the obtained average recovery was in the acceptable range of $80-120 \%$, demonstrating that this novel approach could provide a fast sensor platform option for the future of dengue diagnostics.

Author Contributions: Conceptualization, methodology, writing—original draft preparation, N.A.S.O.; validation, supervision, writing — review and editing, funding acquisition, Y.W.F., J.A. and M.A.M.; software, resources, A.R.S. and N.A.Y.; visualization, I.R. and Y.M.K. All authors have read and agreed to the published version of the manuscript.

Funding: This research was funded and supported by the Exploratory Research Grant Scheme (ERGS/1/2012/STG08/UPM/01/29) and Fundamental Research Grant Scheme (FRGS/1/2019/STG0 2/UPM/02/1) supported this research.

Institutional Review Board Statement: Not applicable.

Informed Consent Statement: Not applicable.

Data Availability Statement: Data sharing not applicable.

Acknowledgments: The authors acknowledged the laboratory facilities provided by the Institute of Advanced Technology, Department of Physics, and Department of Chemistry, Universiti Putra Malaysia.

Conflicts of Interest: The authors declare no conflict of interest. 


\section{References}

1. Saleviter, S.; Fen, Y.W.; Daniyal, W.M.E.M.M.; Abdullah, J.; Sadrolhosseini, A.R.; Omar, N.A.S. Design and analysis of surface plasmon resonance optical sensor for determining cobalt ion based on chitosan-graphene oxide decorated quantum dots-modified gold active layer. Opt. Express 2019, 27, 32294-32307. [CrossRef] [PubMed]

2. Ramdzan, N.S.M.; Fen, Y.W.; Anas, N.A.A.; Omar, N.A.S.; Saleviter, S. Development of biopolymer and conducting polymer-based optical sensors for heavy metal ion detection. Molecules 2020, 25, 2548. [CrossRef]

3. Hashim, H.S.; Fen, Y.W.; Omar, N.A.S.; Daniyal, W.M.E.M.M.; Saleviter, S.; Abdullah, J. Structural, optical and potential sensing properties of tyrosinase immobilized graphene oxide thin film on gold surface. Optik 2020, 212, 1-11. [CrossRef]

4. Daniyal, W.M.E.M.M.; Fen, Y.W.; Abdullah, J.; Sadrolhosseini, A.R.; Saleviter, S.; Omar, N.A.S. Label-free optical spectroscopy for characterizing binding properties of highly sensitive nanocrystalline cellulose-graphene oxide-based nanocomposite towards nickel ion. Spectrochim. Acta Part. A Mol. Biomol. Spectrosc. 2019, 212, 25-31. [CrossRef]

5. Omar, N.A.S.; Fen, Y.W.; Saleviter, S.; Daniyal, W.M.E.M.M.; Anas, N.A.A.; Ramdzan, N.S.M.; Roshidi, M.D.A. Development of a graphene-based surface plasmon resonance optical sensor chip for potential biomedical application. Materials 2019, 12, 1928. [CrossRef]

6. Teng, C.; Zheng, J.; Liang, Q.; Deng, S.; Deng, H.; Liu, H.; Yuan, L. The influence of structural parameters on the surface plasmon resonance sensor based on a side-polished macrobending plastic optical fiber. IEEE Sens. J. 2020, 20, 4245-4250. [CrossRef]

7. Solis-Tinoco, V.; Acevedo-Barrera, A.; Vazquez-Estrada, O.; Munguia-Cervantes, J.; Hernandez-Como, N.; Olguin, L.F.; GarciaValenzuela, A. Fast and accurate optical determination of gold-nanofilms thickness. Opt. Laser Technol. 2021, 134, 1-11. [CrossRef]

8. Omar, N.A.S.; Fen, Y.W.; Abdullah, J.; Kamil, Y.M.; Daniyal, W.M.E.M.M.; Sadrolhosseini, A.R.; Mahdi, M.A. Sensitive detection of dengue virus type 2 E-proteins signals using self-assembled monolayers/reduced graphene oxide-PAMAM dendrimer thin film-SPR optical sensor. Sci. Rep. 2020, 10, 1-15. [CrossRef] [PubMed]

9. Daniyal, W.M.E.M.M.; Fen, Y.W.; Fauzi, N.I.M.; Hashim, H.S.; Ramdzan, N.S.M.; Omar, N.A.S. Recent advances in surface plasmon resonance optical sensors for potential application in environmental monitoring. Sens. Mater. 2020, 32, 4191-4200.

10. Anas, N.A.A.; Fen, Y.W.; Yusof, N.A.; Omar, N.A.S.; Daniyal, W.M.E.M.M.; Ramdzan, N.S.M. Highly sensitive surface plasmon resonance optical detection of ferric ion using CTAB/hydroxylated graphene quantum dots thin film. J. Appl. Phys. 2020, 128, 1-11. [CrossRef]

11. Fauzi, N.I.M.; Fen, Y.W.; Omar, N.A.S.; Saleviter, S.; Daniyal, W.M.E.M.M.; Hashim, H.S.; Nasrullah, M. Nanostructured chitosan/maghemite composites thin film for potential optical detection of mercury ion by surface plasmon resonance investigation. Polymers 2020, 12, 1497. [CrossRef] [PubMed]

12. Ramdzan, N.S.M.; Fen, Y.W.; Omar, N.A.S.; Anas, N.A.A.; Daniyal, W.M.E.M.M.; Saleviter, S.; Zainudin, A.A. Optical and surface plasmon resonance sensing properties for chitosan/carboxyl-functionalized graphene quantum dots thin film. Optik 2019, 178, 802-812. [CrossRef]

13. Fen, Y.W.; Yunus, W.M.M. Utilization of chitosan-based sensor thin films for the detection of lead ion by surface plasmon resonance optical sensor. IEEE Sens. J. 2012, 13, 1413-1418. [CrossRef]

14. Fen, Y.W.; Yunus, W.M.M.; Yusof, N.A. Optical properties of crosslinked chitosan thin film as copper ion detection using surface plasmon resonance technique. Opt. Appl. 2011, 41, 999-1013.

15. Fen, Y.W.; Yunus, W.M.M.; Moksin, M.M.; Talib, Z.A.; Yusof, N.A. Surface plasmon resonance optical sensor for mercury ion detection by crosslinked chitosan thin film. J. Optoelectron. Adv. Mater. 2011, 13, 279-285.

16. Fen, Y.W.; Yunus, W.M.M.; Talib, Z.A. Analysis of $\mathrm{Pb}(\mathrm{II})$ ion sensing by crosslinked chitosan thin film using surface plasmon resonance spectroscopy. Optik 2013, 124, 126-133. [CrossRef]

17. Zainudin, A.A.; Fen, Y.W.; Yusof, N.A.; Omar, N.A.S. Structural, optical and sensing properties of ionophore doped graphene based bionanocomposite thin film. Optik 2017, 144, 308-315. [CrossRef]

18. Daniyal, W.M.E.M.M.; Saleviter, S.; Fen, Y.W. Development of surface plasmon resonance spectroscopy for metal ion detection. Sens. Mater. 2018, 30, 2023-2038. [CrossRef]

19. Daniyal, W.M.E.M.M.; Fen, Y.W.; Abdullah, J.; Sadrolhosseini, A.R.; Saleviter, S.; Omar, N.A.S. Exploration of surface plasmon resonance for sensing copper ion based on nanocrystalline cellulose-modified thin film. Opt. Express 2018, 26, 34880-34893. [CrossRef]

20. Daniyal, W.M.E.M.M.; Fen, Y.W.; Anas, N.A.A.; Omar, N.A.S.; Ramdzan, N.S.M.; Nakajima, H.; Mahdi, M.A. Enhancing the sensitivity of a surface plasmon resonance-based optical sensor for zinc ion detection by the modification of a gold thin film. RSC Adv. 2019, 9, 41729-41736. [CrossRef]

21. Fen, Y.W.; Yunus, W.M.M.; Talib, Z.A.; Yusof, N.A. Development of surface plasmon resonance sensor for determining zinc ion using novel active nanolayers as probe. Spectrochim. Acta A Mol. Biomol. Spectrosc. 2015, 134, 48-52. [CrossRef] [PubMed]

22. Anas, N.A.A.; Fen, Y.W.; Omar, N.A.S.; Daniyal, W.M.E.M.M.; Ramdzan, N.S.M.; Saleviter, S. Development of graphene quantum dots-based optical sensor for toxic metal ion detection. Sensors 2019, 19, 3850. [CrossRef] [PubMed]

23. Fen, Y.W.; Yunus, W.M.M. Surface plasmon resonance spectroscopy as an alternative for sensing heavy metal ions: A review. Sens. Rev. 2013, 33, 305-314.

24. Fen, Y.W.; Yunus, W.M.M.; Yusof, N.A. Surface plasmon resonance optical sensor for detection of $\mathrm{Pb}^{2+}$ based on immobilized p-tert-butylcalix[4]arene-tetrakis in chitosan thin film as an active layer. Sens. Actuators B Chem. 2012, 171-172, 287-293. [CrossRef] 
25. Anas, N.A.A.; Fen, Y.W.; Omar, N.A.S.; Ramdzan, N.S.M.; Daniyal, W.M.E.M.M.; Saleviter, S.; Zainudin, A.A. Optical properties of chitosan/hydroxyl-functionalized graphene quantum dots thin film for potential optical detection of ferric(III) ion. Opt. Laser Technol. 2019, 120, 105724. [CrossRef]

26. Kumar, H.; Kuča, K.; Bhatia, S.K.; Saini, K.; Kaushal, A.; Verma, R.; Bhalla, T.C.; Kumar, D. Applications of nanotechnology in biosensor-based detection of foodborne pathogens. Sensors 2020, 20, 1966. [CrossRef] [PubMed]

27. Elancheziyan, M.; Theyagarajan, K.; Saravanakumar, D.; Thenmozhi, K.; Senthilkumar, S. Viologen-terminated polyamidoamine (PAMAM) dendrimer encapsulated with gold nanoparticles for nonenzymatic determination of hydrogen peroxide. Mater. Today Chem. 2020, 16, 1-9. [CrossRef]

28. Ren, Y.; Wei, J.; He, Y.; Wang, Y.; Bai, M.; Zhang, C.; Luo, L.; Wang, J.; Wang, Y. Ultrasensitive label-free immunochromatographic strip sensor for Salmonella determination based on salt-induced aggregated gold nanoparticles. Food Chem. 2021, 343, 1-8. [CrossRef]

29. Zhu, J.; Ye, Z.; Fan, X.; Wang, H.; Wang, Z.; Chen, B. A highly sensitive biosensor based on au NPs/rGo-PaMaM-Fc nanomaterials for detection of cholesterol. Int. J. Nanomed. 2019, 14, 835-849. [CrossRef]

30. Salvi, L.; Dubey, C.K.; Sharma, K.; Nagar, D.; Meghani, M.; Goyal, S.; Nagar, J.C.; Sharma, A. A synthesis, properties and application as a possible drug delivery systems dendrimers-A review. Asian J. Pharm. Res. Dev. 2020, 8, 107-113. [CrossRef]

31. Hajizadeh, F.; Maleki, B.; Zonoz, F.M.; Amiri, A. Application of structurally enhanced magnetite cored polyamidoamine dendrimer for knoevenagel condensation. J. Iran. Chem. Soc. 2020, 1-12. [CrossRef]

32. Li, Z.; Hu, J.; Yang, L.; Zhang, X.; Liu, X.; Wang, Z.; Li, Y. Integrated POSS-dendrimer nanohybrid materials: Current status and future perspective. Nanoscale 2020, 12, 11395-11415. [CrossRef]

33. Van Tuan, P.; Phuong, T.T.; Tan, V.T.; Nguyen, S.X.; Khiem, T.N. In-situ hydrothermal fabrication and photocatalytic behavior of $\mathrm{ZnO}$ /reduced graphene oxide nanocomposites with varying graphene oxide concentrations. Mater. Sci. Semicond. Process. 2020, 115, 105114. [CrossRef]

34. Zhang, Y.; Sun, L.; Zhang, L.; Li, X.; Gu, J.; Si, H.; Wu, L.; Shi, Y.; Sun, C.; Zhang, Y. Highly porous oxygen-doped NiCoP immobilized in reduced graphene oxide for supercapacitive energy storage. Compos. Part. B Eng. 2020, 182, 1-43. [CrossRef]

35. Syama, S.; Mohanan, P.V. Comprehensive application of graphene: Emphasis on biomedical concerns. Nano-Micro Lett. 2019, 11, 1-31. [CrossRef]

36. Wang, X.; Li, K.; He, J.; Yang, J.; Dong, F.; Mai, W.; Zhu, M. Defect in reduced graphene oxide tailored selectivity of photocatalytic $\mathrm{CO}_{2}$ reduction on $\mathrm{Cs}_{4} \mathrm{PbBr}_{6}$ pervoskite hole-in-microdisk structure. Nano Energy 2020, 78, 1-8. [CrossRef]

37. Sharma, N.; Sharma, V.; Sharma, S.K.; Sachdev, K. Gas sensing behaviour of green synthesized reduced graphene oxide (rGO) for $\mathrm{H}_{2}$ and NO. Mater. Lett. 2019, 236, 444-447. [CrossRef]

38. Hu, S.; Tan, Y.; Feng, C.; Wu, H.; Zhang, J.; Mei, H. Synthesis of N doped NiZnCu-layered double hydroxides with reduced graphene oxide on nickel foam as versatile electrocatalysts for hydrogen production in hybrid-water electrolysis. J. Power Sources 2020, 453, 1-10. [CrossRef]

39. Zeng, Y.; Li, T.; Yao, Y.; Li, T.; Hu, L.; Marconnet, A. Thermally conductive reduced graphene oxide thin films for extreme temperature sensors. Adv. Funct. Mater. 2019, 29, 1-7. [CrossRef]

40. Shu, R.; Wu, Y.; Li, W.; Zhang, J.; Liu, Y.; Shi, J.; Zheng, M. Fabrication of ferroferric oxide-carbon/reduced graphene oxide nanocomposites derived from Fe-based metal-organic frameworks for microwave absorption. Compos. Sci. Technol. 2020, 196, 1-12. [CrossRef]

41. Smith, A.T.; LaChance, A.M.; Zeng, S.; Liu, B.; Sun, L. Synthesis, properties, and applications of graphene oxide/reduced graphene oxide and their nanocomposites. Nano Mater. Sci. 2019, 1, 31-47. [CrossRef]

42. Li, X.; Xie, H.; Mao, J. Ag nanoparticles-reduced graphene oxide hybrid: An efficient electrocatalyst for artificial $\mathrm{N}_{2}$ fixation to $\mathrm{NH}_{3}$ at ambient conditions. J. Mater. Sci. 2020, 55, 5203-5210. [CrossRef]

43. Kubiszeski, J.R.; Vieira, C.J.D.S.P.; Thies, S.F.; Silva, D.J.F.D.; Barreto, E.S.; Mondini, A.; Bronzoni, R.V.D.M. Detection of the Asian II genotype of dengue virus serotype 2 in humans and mosquitoes in Brazil. Rev. Soc. Bras. Med. Trop. 2020, 53, e20190439. [CrossRef] [PubMed]

44. Eldigail, M.H.; Abubaker, H.A.; Khalid, F.A.; Abdallah, T.M.; Musa, H.H.; Ahmed, M.E.; Adam, G.K.; Elbashir, M.I.; Aradaib, I.E. Association of genotype III of dengue virus serotype 3 with disease outbreak in Eastern Sudan, 2019. Virol. J. 2020, 17, 1-8. [CrossRef] [PubMed]

45. Omar, N.A.S.; Fen, Y.W.; Abdullah, J.; Zaid, M.H.M.; Mahdi, M.A. Structural, optical and sensing properties of CdS-NH $\mathrm{COO}$ thin film as a dengue virus E-protein sensing material. Optik 2018, 171, 934-940. [CrossRef]

46. Rana, V.S.; Popli, S.; Saurav, G.K.; Yadav, K.; Kumar, A.; Sunil, S.; Kumar, N.; Singh, O.P.; Natarajan, K.; Rajagopal, R. Aedes aegypti lachesin protein binds to the domain III of envelop protein of Dengue virus-2 and inhibits viral replication. Cell. Microbiol. 2020, 22, 1-15. [CrossRef]

47. Andrade, P.; Narvekar, P.; Montoya, M.; Michlmayr, D.; Balmaseda, A.; Coloma, J.; Harris, E. Primary and secondary dengue virus infections elicit similar memory B-Cell responses, but breadth to other serotypes and cross-reactivity to Zika virus is higher in secondary dengue. J. Infect. Dis. 2020, 222, 590-600. [CrossRef]

48. Tan, K.W.; Tan, B.; Thein, T.L.; Leo, Y.S.; Lye, D.C.; Dickens, B.L.; Wong, J.G.X.; Cook, A.R. Dynamic dengue haemorrhagic fever calculators as clinical decision support tools in adult dengue. Trans. R. Soc. Trop. Med. Hyg. 2020, 114, 7-15. [CrossRef] 
49. Sundaram, A.K.; Ewing, D.; Blevins, M.; Liang, Z.; Sink, S.; Lassan, J.; Raviprakash, K.; Defang, G.; Williams, M.; Porter, K.R.; et al. Comparison of purified psoralen-inactivated and formalin-inactivated dengue vaccines in mice and nonhuman primates. Vaccine 2020, 38, 3313-3320. [CrossRef]

50. Xisto, M.F.; Prates, J.W.O.; Dias, I.M.; Dias, R.S.; Silva, C.C.D.; Paula, S.O.D. NS1 recombinant proteins are efficiently produced in pichia pastoris and have great potential for use in diagnostic kits for dengue virus infections. Diagnostics 2020, 10, 379. [CrossRef]

51. Firdous, S. Laser scanning optical investigations of dengue virus infection from antibody fluorescence of human blood. Laser Phys. Lett. 2019, 16, 1-8. [CrossRef]

52. Andryukov, B.G.; Besednova, N.N.; Romashko, R.V.; Zaporozhets, T.S.; Efimov, T.A. Label-free biosensors for laboratory-based diagnostics of infections: Current achievements and new trends. Biosensors 2020, 10, 11. [CrossRef] [PubMed]

53. Mukherjee, S.; Mukherjee, N. Current Developments in diagnostic biosensor technology: Relevance to therapeutic intervention of infectious and inflammatory diseases of human. In Modern Techniques in Biosensors; Springer: Singapore, 2021; pp. 1-36.

54. Rajamanonmani, R.; Nkenfou, C.; Clancy, P.; Yau, Y.H.; Shochat, S.G.; Sukupolvi-Petty, S.; Schul, W.; Diamond, M.S.; Vasudevan, S.G.; Lescar, J. On a mouse monoclonal antibody that neutralizes all four dengue virus serotypes Lescar. J. Gen. Virol. 2009, 90, 799-809. [CrossRef]

55. Jahanshahi, P.; Zalnezhad, E.; Sekaran, S.D.; Adikan, F.R.M. Rapid immunoglobulin M-based dengue diagnostic test using surface plasmon resonance biosensor. Sci. Rep. 2014, 4, 1-7. [CrossRef]

56. Wong, W.R.; Krupin, O.; Sekaran, S.D.; Adikan, F.R.M.; Berini, P. Serological diagnosis of dengue infection in blood plasma using long-range surface plasmon waveguides. Anal. Chem. 2014, 86, 1735-1743. [CrossRef]

57. Jahanshahi, P.; Sekaran, S.D.; Adikan, F.R.M. Optical and analytical investigations on dengue virus rapid diagnostic test for IgM antibody detection. Med. Biol. Eng. Comput. 2015, 53, 679-687. [CrossRef]

58. Kumbhat, S.; Sharma, K.; Gehlot, R.; Solanki, A.; Joshi, V. Surface plasmon resonance based immunosensor for serological diagnosis of dengue virus infection. J. Pharm. Biomed. Anal. 2010, 52, 255-259. [CrossRef]

59. Fry, S.R.; Meyer, M.; Semple, M.G.; Simmons, C.P.; Sekaran, S.D.; Huang, J.X.; McElnea, C.; Huang, C.; Valks, A.; Young, P.R.; et al. The diagnostic sensitivity of dengue rapid test assays is significantly enhanced by using a combined antigen and antibody testing approach. PLoS Negl. Trop. Dis. 2011, 5, e1199. [CrossRef]

60. Hu, D.; Fry, S.; Huang, J.; Ding, X.; Qiu, L.; Pan, Y.; Chen, Y.; Jin, J.; McElnea, C.; Buechler, J.; et al. Comparison of surface plasmon resonance, resonant waveguide grating biosensing and enzyme linked immunosorbent assay (ELISA) in the evaluation of a dengue virus immunoassay. Biosensors 2013, 3, 297-311. [CrossRef]

61. Wong, W.R.; Sekaran, S.D.; Adikan, F.R.M.; Berini, P. Detection of dengue NS1 antigen using long-range surface plasmon waveguides. Biosens. Bioelectrons. 2016, 78, 132-139. [CrossRef]

62. Jahanshahi, P.; Wei, Q.; Jie, Z.; Ghomeishi, M.; Sekaran, S.D.; Adikan, F.R.M. Kinetic analysis of IgM monoclonal antibodies for determination of dengue sample concentration using SPR technique. Bioengineered 2017, 8, 239-247. [CrossRef]

63. Sjahrurachman, A.; Dewi, B.E.; Lischer, K.; Pratami, D.K.; Flamandita, D.; Sahlan, M. Surface plasmon resonance analysis for detecting non-structural protein 1 of dengue virus in Indonesia. Saudi J. Biol. Sci. 2020, 27, 1931-1937.

64. Liu, L.T.; Chen, C.H.; Tsai, C.Y.; Lin, P.C.; Hsu, M.C.; Huang, B.Y.; Wang, Y.H.; Tsai, J.J. Evaluation of rapid diagnostic tests to detect dengue virus infections in Taiwan. PLoS ONE 2020, 15, 1-14. [CrossRef] [PubMed]

65. da Cruz Santos, C.; Santos, P.C.M.; Rocha, K.L.S.; Thomasini, R.L.; de Oliveira, D.B.; Franco, D.L.; Ferreira, L.F. A new tool for dengue virus diagnosis: Optimization and detection of anti-NS1 antibodies in serum samples by impedimetric transducers. Microchem. J. 2020, 154, 1-10.

66. Omar, N.A.S.; Fen, Y.W.; Abdullah, J.; Sadrolhosseini, A.R.; Mustapha Kamil, Y.; Fauzi, N.I.M.; Hashim, H.S.; Mahdi, M.A. Quantitative and selective surface plasmon resonance response based on a reduced graphene oxide-polyamidoamine nanocomposite for detection of dengue virus e-proteins. Nanomaterials 2020, 10, 569. [CrossRef] [PubMed]

67. Omar, N.A.S.; Fen, Y.W.; Abdullah, J.; Zaid, M.H.M.; Daniyal, W.M.E.M.M.; Mahdi, M.A. Sensitive surface plasmon resonance performance of cadmium sulfide quantum dots-amine functionalized graphene oxide based thin film towards dengue virus E-protein. Opt. Laser Technol. 2019, 114, 204-208. [CrossRef]

68. Wu, S.; Shi, T.; Zhang, L. Preparation and properties of amine-functionalized reduced graphene oxide/waterborne polyurethane nanocomposites. High. Perform. Polym. 2016, 28, 453-465. [CrossRef]

69. Khosroshahi, M.E. Applications of Biophotonics and Nanobiomaterials in Biomedical Engineering; CRC Press: Boca Raton, FL, USA, 2017.

70. Navaee, A.; Salimi, A. Efficient amine functionalization of graphene oxide through the Bucherer reaction: An extraordinary metal-free electrocatalyst for the oxygen reduction reaction. RSC Adv. 2015, 5, 59874-59880. [CrossRef]

71. Sankari, G.; Krishnamoorthy, E.; Jayakumaran, S.; Gunasekaran, S.; Priya, V.V.; Subramaniam, S.; Subramaniam, S.; Mohan, S.K. Analysis of serum immunoglobulins using Fourier transform infrared spectral measurements. Biol. Med. 2010, 2, 42-48.

72. Mossuto, M.F.; Ami, D.; Anelli, T.; Fagioli, C.; Doglia, S.M.; Sitia, R. Biochemical nature of Russell bodies. Sci. Rep. 2015, 5, 1-12.

73. Kamil, Y.M.; Al-Rekabi, S.H.; Yaacob, M.H.; Syahir, A.; Chee, H.Y.; Mahdi, M.A.; Bakar, M.H.A. Detection of dengue using PAMAM dendrimer integrated tapered optical fiber sensor. Sci. Rep. 2019, 9, 1-10.

74. Yoon, S.J.; Kim, D. Thin-film-based field penetration engineering for surface plasmon resonance biosensing. J. Opt. Soc. Am. A 2007, 24, 2543-2549. [CrossRef] 
75. Maharana, P.K.; Jha, R. Chalcogenide prism and graphene multilayer based surface plasmon resonance affinity biosensor for high performance. Sens. Actuators B Chem. 2012, 169, 161-166. [CrossRef]

76. Benazize, S.; Dibi, Z.; Benaziez, N. Optimization of the graphene-silver based surface plasmon resonance (SPR) sensor. Univ. Politeh. Buchar. Sci. Bull. Ser. B 2018, 80, 1454-2331.

77. Bhavsar, K.; Prabhu, R.; Pollard, P. Ultrasensitive graphene coated SPR sensor for biosensing applications. Proc. SPIE 2015, 9506. [CrossRef]

78. Zhang, J.; Sun, Y.; Zhang, H.; Xu, B.; Zhang, H.; Song, D. Preparation and application of triangular silver nanoplates/chitosan composite in surface plasmon resonance biosensing. Anal. Chim. Acta 2013, 769, 114-120. [CrossRef]

79. Lee, Y.K.; Jang, D.H.; Lee, K.S.; Kim, W.M.; Sohn, Y.S. Enhancing performance of a miniaturized surface plasmon resonance sensor in the reflectance detection mode using a waveguide-coupled bimetallic chip. Nanoscale Res. Lett. 2013, 8, 1-8. [CrossRef]

80. Hasan, M.R.; Akter, S.; Rifat, A.A.; Rana, S.; Ahmed, K.; Ahmed, R.; Subbaraman, H.; Abbott, D. Spiral photonic crystal fiber-based dual-polarized surface plasmon resonance biosensor. IEEE Sens. J. 2017, 18, 133-140. [CrossRef]

81. Mustapa, M.A.; Bakar, M.H.A.; Kamil, Y.M.; Syahir, A.; Mahdi, M.A. Bio-functionalized tapered multimode fiber coated with dengue virus NS1 glycoprotein for label free detection of anti-Dengue virus NS1 IgG antibody. IEEE Sens. J. 2018, 18, 4066-4072. [CrossRef]

82. Ida, J.; Kuzuya, A.; Choong, Y.S.; Lim, T.S. An intermolecular-split G-quadruplex DNAzyme sensor for dengue virus detection. RSC Adv. 2020, 10, 33040-33051. [CrossRef]

83. Zakaria, R.; Fahri, M.A.S.A.; Thirunavakkarasu, P.M.; Patel, S.K.; Harun, S.W. High sensitivity refractive index sensor in long-range surface plasmon resonance based on side polished optical fiber. Opt. Fiber Technol. 2021, 61, 1-7. [CrossRef]

84. Ekgasit, S.; Thammacharoen, C.; Knoll, W. Surface plasmon resonance spectroscopy based on evanescent field treatment. Anal. Chem. 2004, 76, 561-568. [CrossRef]

85. Maharana, P.K.; Padhy, P.; Jha, R. On the field enhancement and performance of an ultra-stable SPR biosensor based on graphene. IEEE Photon. Technol. Lett. 2013, 25, 2156-2159. [CrossRef]

86. Hoet, M.; Cohen, E.H.; Kent, R.B.; Rookey, K.; Schoonbroodt, S.; Hogan, S.; Rem, L.; Frans, N.; Daukandt, M.; Pieters, H.; et al. Generation of high-affinity human antibodies by combining donor-derived and synthetic complementarity-determining-region diversity. Nat. Biotechnol. 2005, 23, 344-348. [CrossRef] [PubMed]

87. Salahudeen, M.S.; Nishtala, P.S. An overview of pharmacodynamic modelling, ligand-binding approach and its application in clinical practice. Saudi Pharm. J. 2017, 25, 165-175. [CrossRef] [PubMed]

88. Peters Jr, T. Serum albumin. Adv. Protein Chem. 1985, 37, 161-245.

89. Chew, M.; Poh, K.; Poh, C. Peptides as therapeutic agents for dengue virus. Int. J. Med. Sci. 2017, 14, 1342-1359. [CrossRef]

90. Alen, M.M.F.; Schols, D. Dengue virus entry as target for antiviral therapy. J. Trop. Med. 2012, 2012, 1-13. [CrossRef]

91. Salles, T.S.; Sá-Gulmarães, T.E.; Souza, D.F.D.; López, S.B.G.; Alvarenga, E.S.L.; Franco, T.A.; Melo, A.C.A.; Soares, M.R.; Ferreira, D.F.; Moreira, M.F. Quantitative dengue serotyping: The development of a higher performance method using SYBR Green Assay. Arch. Clin. Microbiol. 2017, 8, 1-12.

92. Hu, Z.; Li, M.; Liu, J.; Yu, L.; Xue, Y.; Chen, Y. Detection of hepatitis b virus large surface protein using a time-resolved immunofluorometric assay. J. Clin. Lab. Anal. 2015, 29, 498-504. [CrossRef]

93. Yañez, V.A.C.; Göpfert, J.C.; Otto, M.; Tumani, H.; Peter, A.; Joos, T.O. Development and validation of an ultrasensitive procalcitonin sandwich immunoassay. High. Throughput 2017, 6, 1-12.

94. Oftedal, L.; Maple-Grødem, J.; Førland, M.G.G.; Alves, G.; Lange, J. Validation and assessment of preanalytical factors of a fluorometric in vitro assay for glucocerebrosidase activity in human cerebrospinal fluid. Sci. Rep. 2020, 10, 1-8. [CrossRef] [PubMed]

95. Bouquet, M.; Passmore, M.R.; Hoe, L.E.S.; Tung, J.P.; Simonova, G.; Boon, A.C.; Fraser, J.F. Development and validation of ELISAs for the quantitation of interleukin (IL)-1 $\beta$, IL-6, IL-8 and IL-10 in ovine plasma. J. Immunol. Methods 2020, 486, 1-7. [CrossRef] [PubMed] 